\title{
SOSIALISASI PEMBERIAN SARI KURMA PADA IBU HAMIL ANEMIA DI \\ KLINIK PRATAMA AFIYAH PEKANBARU TAHUN 2019
}

\author{
Een Husanah , Andrilla Putri \\ STIKes Hang Tuah Pekanbaru
}

\begin{abstract}
Anemia is a situation where the body has the number of red blood cells ( erythrocytes ), too little which red blood cells that contains hemoglobin that serves to carry oxygen to the whole body tissues.Anemia pregnancy is defined as a condition when pregnant women levels of hemoglobin in less than $11,0 \mathrm{gr} / \mathrm{dl}$ on trimester I and III or levels of hemoglobin in less than $10,5 \mathrm{gr} / \mathrm{dl}$. trimester on the $\mathrm{dl}$ The difference the valueof the limit pertaining to hemodilusi.Based on the national demographic health survey ( sdki ) years 2013, the level of anemia for pregnant women by 40,1\% this condition menunjukanbahwa anemia high enough in indonesia. When estimated from years 2007 - 2013 prevelensi anemia still $40 \%$, there will be as much asmother death 18 thousand per year caused bleeding after giving birth.The mortality rate ( aki ) in indonesiais very high namely 30100.000 , per live births the high number was caused among other things by the state of health
\end{abstract}

Keywords: Prenatal, Anemia, Sari Kurma

\begin{abstract}
ABSTRAK
Anemia adalah suatu keadaan dimana tubuh memiliki jumlah sel darah merah (eritrosit) yang terlalu sedikit, yang mana sel darah merah itu mengandung hemoglobin yang berfungsi untuk membawa oksigen ke seluruh jaringan tubuh. Anemia kehamilan didefinisikan sebagai suatu kondisi ketika ibu hamil kadar hemoglobin kurang dari 11,0 gr/dl pada trimester I dan III atau kadar hemoglobin kurang dari 10,5 gr/dL pada trimester II. Perbedaan nilai batas tersebut berkaitan dengan hemodilusi. Berdasarkan data Survei Demografi Kesehatan Nasional (SDKI) tahun 2013, angka anemia pada ibu hamil sebesar 40,1\% kondisi ini menunjukanbahwa anemia cukup tinggi Di Indonesia. Bila diperkirakan dari tahun 2007 2013 prevelensi anemia masih tetap 40\%, maka akan terjadi kematian ibu sebanyak 18 ribu per tahun yang disebabkan perdarahan setelah melahirkan. Angka Kematian Ibu (AKI) Di Indonesia sangat tinggi yaitu 30 per 100.000 kelahiran hidup, tingginya angka tersebut disebabkan antara lain oleh keadaan kesehatan dan gizi ibu yang rendah selama masa hamil. Tujuan pengabdian kepada masyarakat ini mengatasi masalah anemia pada ibu hamil dengan mengkunsumsi sari kurma. Metode yang digunakan dalam kegiatan pengabdian ini adalah penyuluhan, tanya jawab tentang materi yang disampaikan. Hasil menunjukkan bahwa kegiatan yang dilaksanakan dapat mengatasi masalah anemia pada ibu hamil. Diharapkan untuk asuhan pada ibu hamil anemia dapat dilakukan dengan mengkonsumsi sari kurma sehingga bidan praktik mandiri dapat memberikaan asuhan pemberian sari kurma pada ibu hamil yang anemia pada setiap kunjungan antenatal care.
\end{abstract}

\section{Kata Kunci: Ibu hamil, Anemia}

PENDAHULUAN

Anemia adalah suatu keadaan dimana tubuh memiliki jumlah sel darah merah (eritrosit) yang terlalu sedikit, yang mana sel darah merah itu mengandung hemoglobin yang berfungsi untuk 
membawa oksigen ke seluruh jaringan tubuh (Astriana, 2017). Anemia kehamilan didefinisikan sebagai suatu kondisi ketika ibu hamil kadar hemoglobin kurang dari $11,0 \mathrm{gr} / \mathrm{dl}$ pada trimester I dan III atau kadar hemoglobin kurang dari 10,5 gr/dL pada trimester II. Perbedaan nilai batas tersebut berkaitan dengan hemodilusi (Pratami, 2014).

Menurut World Health Organization (WHO), kejadian anemia pada ibu hamil berkisar antara 20\% - 89\% dengan menetapkan kadar $\mathrm{Hb} 11$ gr\% sebagai dasarnya. Menurut laporan pembangunan tahun 2013 tercatat angka kematian ibu di beberapa Negara ASEAN (Assosiation South East Asia Nations) seperti Di Vietnam 18 per 100.000 kelahiran hidup, Malaysia 55 per 100.000 kelahiran hidup, Filiphina 26 per 100.000 kelahiran hidup dan Singapura 3 per 100.000 kelahiran hidup. Di Negara ASEAN pada tahun 2013 angka kejadian anemia berpvariasi, Di Indonesia berkisar 70\%, Filiphina berkisar 55\%, Thailand 45\%, Malaysia $30 \%$, dan Singapura $7 \%$ yang menderita anemia ( Setiowati, 2019).

Berdasarkan data Survei Demografi Kesehatan Nasional (SDKI) tahun 2013, angka anemia pada ibu hamil sebesar $40,1 \%$ kondisi ini menunjukanbahwa anemia cukup tinggi Di Indonesia. Bila diperkirakan dari tahun 2007 - 2013 prevelensi anemia masih tetap 40\%, maka akan terjadi kematian ibu sebanyak 18 ribu per tahun yang disebabkan perdarahan setelah melahirkan. Angka Kematian Ibu (AKI) Di Indonesia sangat tinggi yaitu 30 per 100.000 kelahiran hidup, tingginya angka tersebut disebabkan antara lain oleh keadaan kesehatan dan gizi ibu yang rendah selama masa hamil(Wiulin 2019)

$$
\text { Kurma (phoenix dactylifera) }
$$
termasuk family palme \& sering disebut date palm, memiliki berbagai macam kandungan nutrisi dan dapat berfungsi sebagai obat. Buah kurma merupakan makanan yang mengandung energy tinggi dengan komposisi ideal, didalamnya memiliki kandungan karbohidrat, triptofan, omega-3, vitamin C, vitamin B6, $\mathrm{Ca} 2+, \mathrm{Zn}$, dan Mg. Buah kurma mengandung serat yang sangat tinggi, selain itu juga mengandung kalium, mangan, fosfor, besi, belerang, kalsium juga magnesium yang sangat baik untuk dikonsumsi. Kandungan zat besinya bisa meningkatkan kadar hamoglobin dalam tubuh. Sehingga bagi wanita usia reproduksi dan ibu hamil sangat disaranakan, khasiat tumbuhan herbal belum mendapatkan perhatian dan hal ini perlu dikembangkan. Sari kurma merupakan hasil olahan buah kurma yang memiliki kandungan besi sebesar 1,5 mg per buah (Suyanti, ,2010).

Sari kurma dapat meningkatkan jumlah trambosit, sehingga dengan 
mengkomsumsi sari kurma akan membantu meningkatkan kembali trambosit. Kandungan zat gula dalam sari kurma kurang lebih $80 \%$, kandungan zat gula tersebut sudah diolah secara alami dan tidak berbahaya bagi kesehatan. Sari kurma yang diberikan pada ibu hamil akan mengalami peningkatan kadar hemoglobin yaitu hampir seluruhnya $(93,75 \%)$ dengan kadar hemoglobin normal dan sebagian kecil $(6,25 \%)$ masih mengalami kadar hemoglobin tidak normal (Maydianasari, 2017).

\section{METODE}

\section{Kerangka Pemecahan Masalah}

Metode yang digunakan dalam kegiatan pengabdian ini adalah penyuluhan, tanya jawab tentang materi yang disampaikan serta pemberian sari kurma pada ibu hamil anemia untuk meningkatkan kadar HB. Materi yang disampaikan tentang masalah anemia pada kehamilan, dan manfaat buah kurma pada kehamilan. Setelah penyampaian informasi tentang anemia pada kehamilan kemudian dilanjutkan dengan informasi cara mengkonsumsi sari kurma. Sasaran dalam kegiatan pengabian ini adalah ibu hamil yang mengalami anemia di klinik Pratama Afiyah Pekanbaru. Dalam pengabdian ini juga dilakukan evaluasi, input, proses dan output.

\section{Rancangan Evaluasi}

Evaluasi adalah penilaian terhadap pemahaman materi yang telah disampaikan kepada ibu hamil anemia. Evaluasi dilaksanakan dalam bentuk mengulas kembali materi melalui proses tanya jawab.

Adapun indikator pencapaian dari hasil evaluasi yaitu;

1. Ibu hamil memahami apa yang dijelaskan oleh penyuluh;

2. Ibu hamil aktif dalam kegiatan tanya jawab.

3. Ibu hamil dapat melakukan cara mengkonsumsi Sari Kurma.

\section{Metode Kegiatan}

Kegiatan pengabdian dilakukan dengan cara penyuluhan dengan tema Sosialisasi Pemberian sari kurma pada ibu hamil anemia. Metode yang dilakukan dengan memberikan ceramah langsung dan leafleat berisi materi dan gambar yang menarik serta tanya jawab seputar anemia pada kehamilan dan sosialisasi cara mengkonsumsi sari kurma.

\section{HASIL}

Kegiatan yang dilakukan dalam penyuluhan ini dilaksanakan dalam beberapa tahap yang diawali dengan penyampaian materi terlebih dahulu, 
kemudian setelah diberikan materi melakukan sesi tanya jawab.

Kegiatan penyuluhan ini dilaksanakan pada hari Rabu, tanggal 08 Juli 2019 bertempat di Klinik Pratama Afiyah Pekanbaru. Kegiatan ini memberikan hasil sebagai berikut :.

1. Ibu hamil mengerti tentang Anemia pada kehamilan meliputi definisi penyebab, akibat bagi ibu dan bayi, cara mencegah dan meningkatkan kadar HB.

2. Ibu hamil mengerti cara mengkonsumsi dapat melakukannya dirumah.

\section{PEMBAHASAN}

$\begin{array}{cr}\text { Ibu hamil Sebagian } & \text { besar } \\ \text { mengetahui tentang anemia } & \text { pada }\end{array}$ kehamilan dan sejauh ini ibu hamil hanya megkonsumsi tablet tambah darah untuk dapat meningkatkan kadar HB nya sesuai dengan yang disaran dari klinik. Ibu hamil anemia belum pernah mengetahui mengkonsumsi sari kurma secara rutin dan teratur dapat meningkatkan kadar $\mathrm{Hb}$ pada masa kehamilan.

\section{Maka dilakukan kegiatan} sosialisasi pemberian sari kurma pada ibu hamil anemia. rangkaian acara berjalan dengan baik dan sesuai rencana. Hal ini terbukti antusiasme ibu bhamil saat mengikuti jalannya kegiatan dan aktifnya ibu ibu hamil untuk bertanya tentang masalah-masalah kehamilan yang berkaitan dengan anemia hal ini dikarenakan informasi baru yang mereka dapat tentang manfaat sari kurma bagi ibu hamil.

\section{KESIMPULAN}

Anemia pada kemilan memberikan dampak buruk tidak hanya untuk ibu tetapi juga bayi. Untuk meningkatkan kadar $\mathrm{Hb}$ ibu hamil dapat dilakukan tidak hanya dengan mengkonsumsi tablet tambah darah saja, terbukti sari kurma mempunyai manfaat yang besar buat ibu hamil pada saat hamil dan nifas nanti jika diminum secara rutin dan teratu. Selain ranya yang enak sari kurma tidak memberikan efek samping jika diminum dalam jangka waktu yang lama.

Berdasarkan kegiatan yang telah dilaksanakan, maka dapat disimpulkan beberapa hal yaitu daya serap ibu hamil terhadap materi kegiatan cukup baik, sikap antusias dan rasa ingin tahu ibu hamil sangat baik, dan terjalinnya keakraban dan suasanan kekeluargaan dengan para pemberi materi nara sumber).

\section{SARAN}

Memberikan pendidikan kesehatan kepada ibu hamil bahwa untuk meningkatkan kadar $\mathrm{Hb}$ dalam darah ibu hamil selain mengkonsumsi tablet tambah darah dapat dilakukan dengan cara mengkonsumsi sari kurma secara rutin 
dan teratur sesuai dengan anjuran yang sudah ditetapkan.

\section{DAFTAR PUSTAKA}

Astriana, W. (2017). Kejadian Anemia pada Ibu Hamil Ditinjau dari Paritas dan Usia. 2(2), 123-130.

Cholifah, N., \& Amalia, E. (2017). Aplikasi Pemberian Kurma Sebagai Upaya Peningkatan Kadar Hemoglobin pada Remaja Putri yang Mengalami Anemia. University Research Colloquium Proceeding, (February), 381-387.

Pratami, E. (2014). evidence-based dalam kebidanan. In evidence-based dalam kebidanan (pp. 77-86).yogyakarta : muha medika
Sari, Dactylifera, Nugroho, S., \& Maydianasari, L. (2017). Nutrisi untuk menambah kadar hemoglobin pada tilus betina (Ratusnorvegicus). 12(April), 62-67.

Suyanti, S. (2010). kurma khasiat dan olahannya. In annisa $\mathrm{r}$ shinta $\mathrm{k}$ (Ed.), kurma khasiat dan olahannya (pertama, pp. 5-46). jakarta: penebar swadaya.

Wiulin Setiowati, S. N. (2019). Pengaruh gkatan kadar hemoglobin ibu hamil trimester III (The Influence of Palm Extract (Phoenix Dactylifera) To Increase of Hemoglobin Level To Trimester III Pragnant Woman). 6(1), 85-91. 